\title{
HUBUNGAN DUKUNGAN SOSIAL KELUARGA DENGAN TINGKAT KECEMASAN PASIEN PENYAKIT CA SERVIK YANG MENJALANI KEMOTHERAPI DI RUMAH SAKIT UMUM IMELDA PEKERJA INDONESIA MEDAN
}

\author{
Paskah Rina Situmorang \\ Program Studi S-1 Keperawatan, STIKes Imelda Medan \\ E-mail : paskahsitumorang85@gmail.com
}

\begin{abstract}
Cervical cancer is a disease that attacks the reproductive system in women, namely the uterus that is in the cervical uterus or cervix. In Indonesia the prevalence of cervical cancer is 4.3 per 1000 population. Where the prevalence is very high in Yogyakarta around 9.6 per 1000 people who have cervical cancer. The hope of recovery of cervical cancer sufferers at a very small palliative stage, where sufferers often experience physical and psychosocial suffering, causing anxiety. One treatment for cervical cancer is chemotherapy which can cause anxiety for patients due to the chemotherapy process, as well as its implementation is complicated and requires a relatively large cost. For that we need support from the family in reducing the level of anxiety in patients undergoing chemotherapy. This study aims to identify how the relationship of family social support with anxiety levels of cervical cancer patients. This research is a descriptive correlation study with a cross-sectional study design. The sample in this study were 31 patients who were undergoing chemotherapy, at the Indonesian Hospital Imelda Medan Workers. The sampling technique uses total sampling. The instruments were in the form of family social support questionnaires and anxiety levels of cervical cancer patients undergoing chemotherapy. The results showed a relationship between family social support (Emotional Support, Award Support, Instrumental Support, and Informative Support) with the level of anxiety of patients undergoing chemotherapy where the $p$ value $<0.05$ and this relationship is strong this is indicated by the value of $r=0.656$. It can be concluded that social support from the family is very helpful in reducing the anxiety of patients who are undergoing chemotherapy. For this reason, families are expected to continue to provide social support to patients with cervical cancer undergoing chemotherapy.
\end{abstract}

Keywords : Family Social Support, Anxiety, Cervical Cancer

\begin{abstract}
Abstrak
Kanker serviks merupakan penyakit yang menyerang sistem reproduksi pada wanita yaitu uterus yang berada pada bagian serviks uterus atau leher rahim. Di Indonesia prevalensi angka kejadian kanker serviks 4,3 per 1000 jumlah pendduk. Dimana prevalensi yang sangat tinggi di Yogyakarta sekitar 9,6 per 1000 penduduk yang mengalami kanker serviks. Harapan kesembuhan penderita kanker serviks pada stadium paliatif sangan kecil, dimana penderita sering mengalami penderitaan fisik dan psikososial sehingga menimbulkan kecemasan. Salah satu pengobatan yang dilakukan untuk penyakit kanker serviks adalah dengan kemohterapi yang dapat menimbulkan rasa cemas bagi pasien karena proses kemohterapi, serta pelaksanaanya rumit dan memerlukan biaya yang relatif besar. Untuk itu perlu adanya dukungan dari keluarga dalam mengurangi tingkat kecemasan pada pasien yang menjalani kemohterapi. Penelitian ini bertujuan untuk mengidentifikasi bagaimanakah hubungan dukungan sosial keluarga dengan tingkat kecemasan pasien penyakit kanker serviks. Penelitian ini merupakan penelitian deskriptif korelasi dengan rancangan studi Cross Sectional. Sampel dalam penelitian ini adalah pasien yang menjalani kemohterapi sebanyak 31 orang responden di RSU Imelda Pekerja Indonesia Medan. Tehnik sampling menggunakan Total sampling. Instrumen berupa kuesioner dukungan sosial keluarga dan tingkat kecemasan pasien penyakit kanker serviks yang menjalani kemohterapi. Hasil penelitian menunjukan adanya
\end{abstract}


hubungan antara dukungan sosial keluarga (Dukungan Emosional, Dukungan Penghargaan, Dukungan Instrumental, dan Dukungan Informatif) dengan tingkat kecemasan pasien yang menjalani kemohterapi dimana nilai $\mathrm{p}<0,05$ dan hubungan tersebut kuat hal ini ditunjukan oleh nialai $r=0,656$. Dapat disimpulkan bahwa dukungan sosial dari keluarga sangat membantu dalam mengurangi kecemasan pasien yang sedang menjalani kemohterapi. Untuk itu diharapkan kepada keluarga agar tetap memberikan dukungan sosial pada pasien yang mengalami penyakit kanker serviks yang menjalani kemohterapi.

Kata Kunci : Dukungan Sosial Keluarga, Kecemasan, Kanker serviks.

\section{PENDAHULUAN}

Kanker serviks atau yang sering disebut dengan kanker leher rahim merupakan penyakit mematikan yang menyerang wania, kanker servik merupakan penyebab kematian terbesar bagi wanita khususnya Negara berkembang. Secara keseluruhan terdapat 600.000 kasus baru yang diakibatkan oleh kanker serviks dan sekitar 300.000 yang meninggal setiap tahunnya sekitar $80 \%$ hal ini membuat kanker serviks mendapat urutan kedua kanker terbanyak pada perempuan di dunia, dan menempati urutan pertama di Negara berkembang.

Menurut data World Health Organization (WHO), tahun 2012 diketahui terdapat sekitar 530.000 kasus pasien baru yang mengalami kanker servik di seluruh dunia.Dan lebih dari 270.000 orang wanita meninggal setiap tahunnya akibat penyakit kanker servik, lebih dari $85 \%$ dari angka kematian ini terjadi di Negara-negara yang memiliki penghasilan rendah dan menengah dimana salah satunya adalah Negara Indonesia.

Menurut data yang dikeluarkan oleh Pusat data dan Informasi Kementerian Kesehatan Republik Indonesia pada tahun 2013 terdapat sekitar 98.692 orang penderita kanker servik di Indonesia (Kementerian Kesehatan Republik Indonesia, 2015). Data yang diperoleh melalui Pusat informasi tahun 2011 sampai 2013 diketahui dari data Rumah Sakit Kanker Darmais pada tahun 2011 terjadi 35 kasus kanker servik yang meninggal dunia, tahun 2012 sekitar 42 orang yang meninggal dunia, dan tahun 2013 sekitar 65 orang yang meninggal dunia akibat kanker servik. Data Riskesdas tahun 2007 menunjukkan jumlah prevalensi kanker berjumlah 4,3 per 1000 penduduk di Indonesia.
Pengobatan kanker yang paling sering dilakukan adalah dengan cara kemoterapi. Menurut Fauziana tahun 2011 kemohterapi merupakan proses pemberian obat-obatan anti kanker dalam bentuk pil cair atau berupa kapsul melalui infuse dimana bertujuan untuk membunuh sel kanker, namun tidak hanya sel kanker tetapi juga sel-sel yang ada di seluruh tubuh. Kemohterapi mempunyai efek samping pada fisik dan psikologis pada penderita kanker. Efek samping fisik kemohterapi yang umum adalah mual muntah, perubahan rasa kecap, rambut menjadi rontok (alopecial), Mukositis, dermatitis, keletihan, kulit menjadi kering bahkan menjadi kaku dan terkadang kulit menjadi menghitam, tidak adanya nafsu makan, dan rasa ngilu pada tulang (Nisam, 2011). Efek samping fisik tersebut memberikan efek yang berdampak pada psikologis pasien kanker yang dapat menyebabkan pasien kanker merasa tidak nyaman, cemas bahkan trkadang takut saat menghadapi kemohterapi.

Penelitian yang dilakukan Desiani tahun 2008 tentang tingkat kecemasan pasien yang menjalani kemohterapi dari responden yang berjumlah 54 diketahui sebahagian besar responden mengalami kecemasan sedang. Kecemasan sedang membuat pasien terfokus pada pikiran yang menjadi perhatiannya, tetapi masih bisa melakuan sesuatu dengan arahan oleh orang lain. Kecemasan merupakan bagian dari kehidupan manusia yang mana ditandai dengan adanya rasa takut atau kekhawatiran yang mendalam dan berkelanjutan (Nadeak, 2010). Kecemasan yang berlebih pada pasien yang menjalani kemohterapi dapat mempengaruhi motivasi pasien dalam menjalankan kemohterapi sehingga dapat mempengaruhi pada proses kemohterapi sendiri (Lutfa, 2008). Efek samping yang sering timbul 
pada pasien rasa tidak nyaman, takut, cemas, malas bahkan bisa sampai frustasi atau putus asa dengan pengobatan yang sedang dilakukan oleh pasien hal ini sangat membutuhkan dukungan dari keluarga (Ratna, 2010).

Rasa cemas merupakan perasaan yang tidak menyenangkan atau ketakutan yang tidak jelas dan hebat. Cemas merupakan suatu hal yang tidak dapat terhindarkan dalam kehidupan manusia. Walaupun cemas merupakan hal yang wajar namun bila cemas yang berlebih dan terus menerus akan menganggu sehingga dapat memperburuk keadaan seseorang. Oleh sebab itu kecemasan merupakan tantangan yang harus diatasi dalam kehidupan manusia (Nugroho, 1995).

Kecemasan pada pasien yang menjalani kemohterapi dapat terjadi akibat terapi yang berlangsung seumur hidup dan pasien ketergantungan dan membutuhkan waktu yang lama serta memerlukan biaya yang relatif besar. Untuk mengatasi gangguan psikologis tersebut diperlukan dukungan sosial keluarga agar dapat menurunkan efek psikologis yang ditimbulkan (Lumenta, 1992).

Dukungan sosial terdiri dari dua yang terdiri dari dukungan emosional merupakan bentuk dukungan yang membuat individu memiliki perasaan nyaman, yakin, dipedulikan, dan dicintai oleh keluarga sehingga individu dapat menghadapi masalah dengan lebih baik. Dukungan penghargaan yaitu dukungan yang diberikan oleh keluarga untuk membangun harga diri dan kompetensi individu. Dukungan instrumental yaitu dukungan yang diberikan oleh keluarga berupa uang, barang, makanan, serta pelayanan. Dukungan informatif yaitu upaya yang dilakukan oleh keluarga kepada pasien berupa informasi, saran atau umpan balik tentang situasi dan kondisi individu (Friedman, 1998).

Jhender Sareen, MD (2005) dalam Anxiety Disorders Increase of Suicidal Thoughts and Attemps hasil penelitiannya menyatakan bahwa dukungan sosial keluarga sangat dibutuhkan sebab jika tidak, akan menyebabkan depresi pada pasien dan akhirnya dapat menyebabkan tindakan bunuh diri.

Berdasarkan hasil studi pendahuluan yang dilakukan peneliti kepada 5 (lima) orang yang menjalani kemohterapi 2 (dua) orang mengatakan kurang mendapat dukungan informasi dari keluarga, dan 1 orang mengatakan kurang mendapat dukungan instrumental dan 2 orang mengatakan kurang mendapatkan dukungan emosional dan dukungan penghargaan dari keluarga.

Berdasarkan hal tersebut diatas maka peneliti ingin mengetahui bagaimana hubungan dukungan sosial keluarga dengan tingkat kecemasan pasien penyakit kanker serviks yang menjalani kemohterapi di RSU. Imelda Pekerja Indonesia Medan.

\section{METODE PENELITIAN}

Penelitian ini merupakan jenis penelitian deskriptif korelasi dengan rancangan studi Cross Sectional, karena bertujuan untuk mengetahui apakah ada hubungan dukungan social keluarga dengan tingkat kecemasan pasien yang mengalami penyakit kanker serviks yang menjalani kemohterapi di Rumah Sakit Umum Imelda Pekerja Indonesia Medan. Populasi dalam penelitian ini seluruh pasien yang mengalami penyakit kanker serviks yang menjalani kemohterapi sebanyak 31 orang. Tehnik pengambilan sampel dalam penelitian ini dengan menggunakan tehnik total sampel dimana seluruh populasi diambil menjadi sampel. Analisa data dilakukan dengan analisa univariat dan bivariat dimana uji univariat untuk mengetahui distribusi frekuensi dari masing-masing variabel bebas dan variabel terikat. Analisa bivariat untuk mengetahui hubungan dan kekuatan antara variabel bebas dan variabel terikat dengan menggunakan uji statistik Spearman

\section{HASIL PENELITIAN}

Karakteristik responden yang menderita kanker serviks yang menjalani kemohterapi di Rumah Sakit Umum Imelda pekerja Indonesia medan berdasarkan data demografi responden diketahui bahwa mayoritas umur responden yang menjalani kemohterapi <45 Tahun 20 orang $(64,5 \%)$, mayoritas berpendidikan SLTA 20 orang (64,5\%), Berdasarkan agama mayoritas responden beragama Kristen 18 orang $(58,1 \%)$, 
Mayoritas pekerjaan responden Pegawai swasta 11 orang $(35,5 \%)$.

Berdasarkan dukungan sosial keluarga meliputi dukungan emosional diketahui bahwa mayoritas responden mendapat dukungan emosional keluarga dengan kategori baik 16 orang $(51,6 \%)$ dan minoritas 3 orang $(9,7 \%)$. Berdasarkan dukungan penghargaan bahwa mayoritas responden mendapat dukungan penghargaan keluarga dengan kategori baik 15 orang $(48,4 \%)$ dan minoritas 3 orang $(9,7 \%)$. Berdasarkan dukungan Instrumental bahwa responden mendapat dukungan instrumental keluarga dengan kategori baik 14 orang $(45,2 \%)$, dan minoritas 3 orang $(9,7 \%)$. Berdasarkan dukungan Informatif bahwa mayoritas responden mendapat dukungan informatif keluarga dengan kategori baik 16 orang $(51,6 \%)$, dan minoritas 3 orang $(9,7 \%)$. Berdasarkan dukungan sosial keluarga bahwa mayoritas responden mendapat dukungan sosial keluarga dengan kategori baik 14 orang $(45,2 \%)$, dan minoritas 4 orang $(12.9 \%)$.

Berdasarkan tingkat kecemasan pasien yang mengalami kanker serviks yang menjalani kemohterapi di Rumah sakit Umum Imelda pekerja Indonesia Medan diketahui bahwa mayoritas responden yang menjalani kemohterapi dengan tingkat kecemasan sedang 19 orang $(61,3 \%)$, sedangkan minoritas responden dengan tingkat kecemasan berat $(12,9 \%)$.

Berdasarkan dukungan sosial keluarga dengan tingkat kecemasan pasien yang menjalani kemohterapi berdasarkan dukungan emosional ketahui bahwa $(51,6 \%)$ responden mendapat dukungan emosional yang baik dari keluarga, dari $(51,6 \%)$ tersebut $(25,8 \%)$ mengalami cemas ringan, $(22,6 \%)$ mengalami cemas sedang, dan $(3,2 \%)$ mengalami cemas berat, sedangkan $(38,7 \%)$ responden mendapat dukungan emosional yang cukup dari keluarga dengan tingkat kecemasan sedang, dan $(9,7 \%)$ responden mendapat dukungan emosional kurang dengan tingkat kecemasan berat. Berdasarkan dukungan penghargaan diketahui bahwa $(48,4 \%)$ responden mendapat dukungan penghargaan yang baik dari keluarga, dari $(48,4 \%)$ tersebut $(25,8 \%)$ mengalami cemas ringan, $(19,4 \%)$ mengalami cemas sedang, dan
$(3,2 \%)$ mengalami cemas berat, sedangkan $(41,9 \%)$ responden mendapat dukungan penghargaan yang cukup dari keluarga dengan tingkat kecemasan sedang, dan $(9,7 \%)$ responden mendapat dukungan penghargaan kurang dengan tingkat kecemasan berat. Bedasarkan dukungan instrumental diketahui ketahui bahwa $(45,2 \%)$ responden mendapat dukungan instrumental yang baik dari keluarga, dari $(45,2 \%)$ tersebut $(25,8 \%)$ mengalami cemas ringan, $(16,1 \%)$ mengalami cemas sedang, dan $(3,2 \%)$ mengalami cemas berat, sedangkan $(45,2 \%)$ responden mendapat dukungan instrumental yang cukup dari keluarga dengan tingkat kecemasan sedang, dan $(9,7 \%)$ responden mendapat dukungan instrumental kurang dengan tingkat kecemasan berat. Berdasarkan dukungan informatif diketahui bahwa $(51,6 \%)$ responden mendapat dukungan informatif yang baik dari keluarga, dari $(51,6 \%)$ tersebut $(25,8 \%)$ mengalami cemas ringan, $(22,6,1 \%)$ mengalami cemas sedang, dan $(3,2 \%)$ mengalami cemas berat, sedangkan $(38,7 \%)$ responden mendapat dukungan informatif yang cukup dari keluarga dengan tingkat kecemasan sedang, dan $(9,7 \%)$ responden mendapat dukungan instrumental kurang dengan tingkat kecemasan berat. Berdasarkan dukungan sosial keluarga diketahui bahwa $(45,2 \%)$ responden mendapat dukungan sosial keluarga yang baik dari keluarga, dari (45,2\%) tersebut (25,8\%) mengalami cemas ringan, $(16,1 \%)$ mengalami cemas sedang, dan $(3,2 \%)$ mengalami cemas berat, sedangkan $(41,9 \%)$ responden mendapat dukungan sosial keluarga yang cukup dari keluarga dengan tingkat kecemasan sedang, dan $(12,9 \%)$ responden mendapat dukungan sosial keluarga kurang, dari $(12,9 \%)$ tersebut $(3,2 \%)$ mengalami cemas sedang, dan $(9,7 \%)$ mengalami cemas berat.

Berdasarkan Uji Statistik yang meliputi dukungan emosional menunjukkan adanya hubungan antara dukungan emosional keluarga dengan tingkat kecemasan pasien penyakit kanker serviks yang menjalani kemohterapi dimana nilai $\mathrm{p}<0,05$ dan hubungan tersebut kuat hal ini ditunjukan oleh nilai $r=0,626$. Dukungan penghargaan menunjukkan adanya hubungan antara dukungan penghargaan 
keluarga dengan tingkat kecemasan pasien penyakit kanker serviks yang menjalani kemohterapi dimana nilai $p<0,05$ dan hubungan tersebut kuat hal ini ditunjukan oleh nilai $r=0,648$. Dukungan Instrumental menunjukkan adanya hubungan antara dukungan instrumental keluarga dengan tingkat kecemasan pasien penyakit kanker serviks yang menjalani kemohterapi dimana nilai $\mathrm{p}<0,05$ dan hubungan tersebut kuat hal ini ditunjukan oleh nilai $r=0,671$. Dukungan Informatif menunjukkan adanya hubungan antara dukungan informatif keluarga dengan tingkat kecemasan pasien penyakit kanker serviks kronis yang menjalani kemohterapi dimana nilai $\mathrm{p}<0,05$ dan hubungan tersebut kuat hal ini ditunjukan oleh nilai $r=0,626$. Dukungan sosial keluarga menunjukkan adanya hubungan antara dukungan sosial keluarga dengan tingkat kecemasan pasien penyakit kanker serviks yang menjalani kemohterapi dimana nilai $\mathrm{p}<0,05$ dan hubungan tersebut kuat hal ini ditunjukan oleh nilai $r=0,656$

\section{PEMBAHASAN}

Hubungan Dukungan Emosional Keluarga Dengan Tingkat Kecemasan Pasien Penyakit Kanker Servik Yang Menjalani Kemotherapi

Hasil penelitian antara dukungan emosional dengan tingkat kecemasan diketahui bahwa 16 orang $(51,6 \%)$ responden mendapat dukungan emosional yang baik dari keluarga, dari 16 orang $(51,6 \%)$ tersebut 8 orang $(25,8 \%)$ mengalami cemas ringan, 7 orang $(22,6 \%)$ mengalami cemas sedang, dan 1 orang $(3,2 \%)$ mengalami cemas berat, sedangkan 12 orang $(38,7 \%)$ responden mendapat dukungan emosional yang cukup dari keluarga dengan tingkat kecemasan sedang, dan 3 orang $(9,7 \%)$ responden mendapat dukungan emosional kurang dengan tingkat kecemasan berat.

Uji statistik Spearman didapat $\mathrm{p}<0,05$ menunjukkan adanya hubungan dukungan emosional keluarga dengan tingkat kecemasan pasien yang menjalani kemohterapi, dan hubunganya kuat hal ini ditunjukan oleh nilai $r$ $=0,626$.

Penelitian ini didukung oleh pendapat Friedman (1998), yang mengatakan bahwa dukungan sosial keluarga dapat menurunkan efek cemas dengan meningkatkan kesehatan mental individu atau keluarga, dukungan sosial merupakan strategi koping yang sangat penting bagi keluarga yang diperoleh pada saat stres karena dukungan sosial merupakan strategi dalam pencegahan untuk menurunkan kecemasan dan akibat negatif dari cemas tersebut.

Hasil penelitian yang diperoleh, penulis menyimpulkan bahwa semakin baik dukungan emosional keluarga terhadap pasien yang mengalami penyakit kanker serviks maka semakian rendah tingkat kecemasan pasien yang menjalani kemohterapi, oleh karena itu diharapkan bagi keluarga dan perawat agar selalu memberikan dukungan emosional dengan memberikan rasa nyaman, dengan selalu meyakinkan pasien, selalu peduli terhadap pasien sehingga pasien dapat menghadapi masalah dengan baik.

\section{Hubungan Dukungan Penghargaan Dengan Tingkat Kecemasan Pasien Penyakit Kanker Servik Yang Menjalani Kemotherapi}

Hasil penelitian dukungan penghargaan dengan tingkat kecemasan dapat diketahui bahwa bahwa 15 orang $(48,4 \%)$ responden mendapat dukungan penghargaan yang baik dari keluarga, dari 15 orang $(48,4 \%)$ tersebut 8 orang $(25,8 \%)$ mengalami cemas ringan, 6 orang $(19,4 \%)$ mengalami cemas sedang, dan 1 orang $(3,2 \%)$ mengalami cemas berat, sedangkan 13 orang $(41,9 \%)$ responden mendapat dukungan penghargaan yang cukup dari keluarga dengan tingkat kecemasan sedang, dan 3 orang $(9,7 \%)$ responden mendapat dukungan penghargaan kurang dengan tingkat kecemasan berat

Uji statistik Spearman didapat $\mathrm{p}<0,05$ menunjukkan adanya hubungan dukungan penghargaan keluarga dengan tingkat kecemasan pasien yang menjalani kemohterapi, dan hubunganya kuat hal ini ditunjukan oleh nilai $r=0,648$.

Penelitian ini didukung oleh pendapat Smeltzer (2001) dan Friedman (1998) mengemukakan bahwa dukungan sosial keluarga berfungsi meningkatkan kesehatan dan adaptasi keluarga, selain memberikan 
keuntungan psikososial, dukungan sosial juga menunjukkan kemungkinan timbulnya kesakitan yang lebih sedikit, lebih cepat sembuh dari sakit (Kulik \& Mahler, 1989, dikutip dari Taylor 1995) Dukungan sosial keluarga yang tinggi dapat menurunkan gangguan psikologis dan fisik karena munculnya stresor. Dukungan sosial yang berasal dari dalam keluarga membuat seseorang merasakan kenyamanan, diperhatian, penghargaan dan bila menerima kondisinya. Tersedianya dukungan sosial menunjukkan kemungkinan munculnya rasa sakit yang lebih rendah, cepat sembuh dari rasa sakit yang diderita. Dukungan sosial juga dapat dihubungkan dengan penyesuaian diri menjadi lebih baik dan menurunkan rasa cemas dari rasa sakit yang dideritanya, kesembuhan pasien akan lebih cepat (Diamond, 1979 dalam Taylor, 1995).

Hasil penelitian yang telah diperoleh, penulis menyimpulkan bahwa semakin baik dukungan penghargaan dari keluarga terhadap pasien yang menjalani kemohterapi maka semakin rendah tingkat kecemasan pasien yang menjalani kemohterapi, untuk itu diharapkan bagi keluarga dan perawat agar selalu memberikan dukungan penghargaan yaitu selalu memberi semangat, serta menghargai keputusan pasien sehingga pasien merasa dihargai walaupun dalam keadaan sakit.

\section{Hubungan Dukungan Instrumental Dengan Tingkat Kecemasan Pasien Penyakit Kanker Servik Yang Menjalani Kemotherapi}

Hasil penelitian dukungan instrumental dengan tingkat kecemasan pasien diketahui bahwa 14 orang $(45,2 \%)$ responden mendapat dukungan instrumental yang baik dari keluarga, dari 14 orang $(45,2 \%)$ tersebut 8 orang $(25,8 \%)$ mengalami cemas ringan, 5 orang $(16,1 \%)$ mengalami cemas sedang, dan 1 orang $(3,2 \%)$ mengalami cemas berat, sedangkan 14 orang $(45,2 \%)$ responden mendapat dukungan instrumental yang cukup dari keluarga dengan tingkat kecemasan sedang, dan 3 orang $(9,7 \%)$ responden mendapat dukungan instrumental kurang dengan tingkat kecemasan berat.

Uji statistik Spearman didapat $\mathrm{p}<0,05$ menunjukkan adanya hubungan dukungan instrumental keluarga dengan tingkat kecemasan pasien yang menjalani kemohterapi dan hubunganya kuat hal ini ditunjukan oleh nilai $r=0,671$.

Penelitian ini didukung oleh pendapat Smeltzer (2001) dan Friedman (1998) yang mengatakan bahwa dukungan sosial keluarga mampu berfungsi dalam meningkatkan kesehatan dan adaptasi keluarga, selain memberikan keuntungan psikososial, dukungan sosial juga menunjukkan kemungkinan timbulnya kesakitan lebih sedikit, lebih cepat sembuh dari sakit (Kulik \& Mahler, 1989, dikutip dari Taylor 1995). Dukungan sosial keluarga yang tinggi maka akan menurunkan gangguan psikologis dan fisik karena munculnya stressor. Bahwa dukungan sosial keluarga yang berasal dari keluarga membuat seseorang merasakan kenyamanan, perhatian, penghargaan dan bila menerima kondisinya. Manfaat tersedianya dukungan sosial menunjukkan kemungkinan munculnya rasa sakit yang lebih rendah lebih cepat sembuh dari rasa sakit yang diderita . dukungan sosial juga dihubungkan dengan penyesuaian diri lebih baik dan menurunkan rasa cemas dari rasa sakit yang dideritanya, kesembuhan pasien lebih cepat ( Diamond, 1979 dalam Taylor, 1995).

Hasil Penelitian yang telah diperoleh, penulis menyimpulkan bahwa semakin baik dukungan instrumental keluarga terhadap pasien yang mengalami kemohterapi maka semakian rendah tingkat kecemasan pasien yang menjalani kemohterapi, untuk itu diharapkan bagi keluarga agar tetap memberikan dukungan instrumental berupa pertolongan langsung berupa materi, barang, makanan, serta pelayanan sehingga dapat mengurangi kecemasan terhadap pasien.

\section{Hubungan Dukungan Informatif Dengan Tingkat Kecemasan Pasien Penyakit Kanker Servik Yang Menjalani Kemotherapi}

Hasil penelitian dukungan informatif dengan tingkat kecemasan di ketahui bahwa 16 orang $(51,6 \%)$ responden mendapat dukungan informatif yang baik dari keluarga, dari 16 orang $(51,6 \%)$ tersebut 8 orang $(25,8 \%)$ mengalami cemas ringan, 7 orang $(22,6,1 \%)$ 
mengalami cemas sedang, dan 1 orang $(3,2 \%)$ mengalami cemas berat, sedangkan 12 orang $(38,7 \%)$ responden mendapat dukungan informatif yang cukup dari keluarga dengan tingkat kecemasan sedang, dan 3 orang $(9,7 \%)$ responden mendapat dukungan instrumental kurang dengan tingkat kecemasan berat

Uji statistik Spearman didapat $\mathrm{P}=$ $0,000<0,05$ menunjukkan adanya hubungan dukungan informatif keluarga dengan tingkat kecemasan pasien kemohterapi, dan hubunganya kuat hal ini ditunjukan oleh nilai $r$ $=0,626$.

Penelitian ini didukung oleh pendapat Friedman (1998) yang mengatakan bahwa dukungan sosial dari kelurga dapat menurunkan efek cemas dengan meningkatkan kesehatan mental individual atau keluarga secara langsung, dukungan sosial merupakan strategi koping yang sangat penting yang diperoleh pada saat mengalami stres karena dukungan sosial sebagai strategi pencegahan dalam menurunkan kecemasan dan akibat negatif dari cemas tersebut.

Hasil penelitian yang telah diperoleh, penulis menyimpulkan bahwa semakin baik dukungan informatif keluarga kepada pasien yang mengalami kemohterapi maka semakian rendah tingkat kecemasan orang yang menjalani kemohterapi, oleh kerena itu diharapkan bagi keluarga dan perawat untuk tetap memberikan dukungan informatif berupa informasi, saran atau umpan balik tentang situasi dan kondisi pasien agar pasien dapat mengenali dan mengatasi masalah dengan lebih mudah.

\section{Hubungan Dukungan Sosial Keluarga Dengan Tingkat Kecemasan Pasien Penyakit Kanker Serviks Yang Menjalani Kemotherapi}

Hasil penelitian dukungan sosial keluarga dengan tingkat kecemasan diketahui bahwa 14 orang $(45,2 \%)$ responden mendapat dukungan sosial keluarga yang baik dari keluarga, dari 14 orang $(45,2 \%)$ tersebut 8 orang $(25,8 \%)$ mengalami cemas ringan, 5 orang $(16,1 \%)$ mengalami cemas sedang, dan 1 orang $(3,2 \%)$ mengalami cemas berat, sedangkan 13 orang $(41,9 \%)$ responden mendapat dukungan sosial keluarga yang cukup dari keluarga dengan tingkat kecemasan sedang, dan 4 orang $(12,9 \%)$ responden mendapat dukungan sosial keluarga kurang, dari 4 orang $(12,9 \%)$ tersebut 1 orang $(3,2 \%)$ mengalami cemas sedang, dan 3 orang $(9,7 \%)$ mengalami cemas berat.

Uji statistik Spearman didapat $\mathrm{P}=$ $0,000<0,05$ menunjukkan adanya hubungan dukungan sosial keluarga dengan tingkat kecemasan pasien yang menjalani kemohterapi, dan hubunganya kuat hal ini ditunjukan oleh nilai $r=0,656$.

Dukungan sosial dari kelurga dapat menurunkan efek cemas dengan meningkatkan kesehatan mental individual atau keluarga secara langsung, dukungan sosial merupakan strategi koping keluarga yang sangat penting diperoleh pada saat stres karena dukungan sosial sebagai strategi pencegahan untuk menurunkan kecemasan dan akibat negatif dari cemas tersebut (Friendman, 1998).

Hasil penelitian yang telah diperoleh, penulis menyimpulkan bahwa semakin baik dukungan sosial keluarga terhadap pasien yang menjalani kemohterapi maka semakian rendah tingkat kecemasan pasien yang menjalani kemohterapi, untuk itu diharapkan bagi keluarga agar selalu memberikan dukungan sosial (emosional, penghargaan, instrumental, informatif) agar pasien patuh dan lebih siap menjalani kemohterapi.

\section{KESIMPULAN}

Hasil penelitian mengenai hubungan antara dukungna sosial keluarga dengan tingkat kecemasan pasien penyakit kanker serviks yang menjalani kemohterapi di RSU Imelda Pekerja Indonesia Medan Tahun 2019 dapat disimpulkan bahwa:

1. Adanya hubungan antara dukungan emosional keluarga dengan tingkat kecemasan pasien yang menjalani kemohterapi dimana nilai $\mathrm{p}<0,05$ dan hubunganya kuat hal ini ditunjukan oleh nilai $r=0,626$.

2. Adanya hubungan antara dukungan penghargaan dengan tingkat kecemasan pasien yang menjalani kemohterapi dimana 
nilai $\mathrm{p}<0,05$ dan hubunganya kuat hal ini ditunjukan oleh nilai $r=0,648$.

3. Adanya hubungan antara dukungan instrumental keluarga dengan tingkat kecemasan pasien yang menjalani kemohterapi dimana nilai $\mathrm{p}<0,05$ dan hubunganya kuat hal ini ditunjukan oleh nilai $r=0,671$.

4. Adanya hubungan antara dukungan informatif keluarga dengan tingkat kecemasan pasien yang menjalani kemohterapi dimana nilai $\mathrm{p}<0,05$ dan hubunganya kuat hal ini ditunjukan oleh nilai $r=0,626$.

5. Adanya hubungan antara dukungan sosial keluarga dengan tingkat kecemasan pasien yang menjalani kemohterapi dimana nilai $p$ $<0,05$ dan hubunganya kuat hal ini ditunjukan oleh nilai $r=0,656$.

\section{SARAN}

\section{Bagi Keluarga}

Agar selalu memberikan rasa nyaman, rasa percaya, peduli, memberi semangat, dan selalu melibatkan pasien dalam pengambilan keputusan, memberikan informasi yang baik, saran, mengenai kondisi pasien agar kecemasan pasien yang menjalani kemohterapi berkurang.

2. Bagi Perawat

Sebaiknya sebagai seorang perawat selain memberikan pengobatan dan terapi juga harus memberikan dukungan seperti memberikan rasa nyaman, memberi semangat, dan selalu meyakinkan pasien agar tidak cemas saat menjalani kemohterapi khususnya saat pasien datang berobat sendiri ke rumah sakit.

\section{REFERENSI}

Arikunto, S. (2002). Prosedur Penelitian: Suatu Pendekatan Praktek. Edisi V. Penerbit Rineka Cipta, Jakarta.

Burn \& Davidson. (1994). Terapi Kognitif untuk Depresi dan Kecemasan Suatu Petunjuk bagi Praktisi, Cetakan I, Penerbit IKIP Semarang Press, Semarang.

Corwin, J. E. (1996). Buku Saku Patofisiologi. Bandung: EGC.
Desiani. (2008). Gambaran tingkat kecemasan pasien kaner payudara yang menjalani kemohterapi di RSUD Al Ihsan Kebupaten Bandung yang telah menerakan Spiritual Care. Diperoleh pada tanggal 7 Agustus 2019 dari http://pustaka.unpad.ac.id/archives/1 28582

Friedman, M. M. (1998). Keperawatan Keluarga: Teori dan Praktik. Edisi III. Penerbit EGC, Jakarta.

Hawari, D. (2001). Manajemen Sres, Cemas dan Depresi. Cetakan II, Jakarta, FKUI.

Hidayat. A. A. (2003). Riset Keperawatan dan Teknik penulisan ilmiah. Edisi I, Penerbit Salemba Medika, Jakarta

Hudak \& Gallo. (1996). Keperawatan Kritis Pendekatan Holistik. Volume II, Edisi VI, Cetakan I, Penerbit EGC. Jakarta.

Kaplan \& Sadock. (1998). Ilmu Kedokteran Jiwa Darurat. cetakan I, Widya Medika. Jakarta.

Langulung, H. (1986). Teori-teori Kesehatan Mental. Cetakan I. Penerbit pustaka AL-Husna, Jakarta.

Lutfa, U \& Maliya, A (2008). Faktor-Faktor yang mempengaruhi kecemasan pasien dalam tindakan kemohterapi di Rumah Sakit Dr. Moewardi Surakarta. Diperoleh pada tanggal 10 Juni 2019 dari

Mansjoer A, dkk. (2000). Kapita Selekta Kedokteran. Edisi III. Penerbit Media Aesculapius, Jakarta.

Notoatmodjo, S. (2002). Metodologi penelitian Kesehatan. Penerbit PT. Rineka cipta, Jakarta.

Nursalam. (2003). Konsep dan Penerapan Metodelogi Penelitian Ilmu Keperawatan.. Penerbit Salemba Medika. Jakarta.

Nadeak, R.J. (2010). Hubungan dukungan keluarga dengan tingkat kecemasan pasien pre operasi di ruang RB2 RSUP HAM. Diiperoleh pada tanggal 8 Juli 2019 dari http://repository.usu.ac.id

Ratna, W. (2010). Sosiologi dan antropologi kesehatan. Yogyakarta : Pustaka Rihama 
Suddart \& Brunner. (1999). Keperawatan Medikal Bedah, Edisi 8. EGC. Jakarta.

Tjokronegoro. (2001). Buku Ajar Ilmu Penyakit Dalam. Edisi 3. FKUI. Jakarta.

World Health Organization (WHO). (2013). Bulletin of The World Health Organization 2012, 0: 478-478 A

Yayasan Kanker Indonesia (YKI). (2011).www.yayasan kanker indonesia.com

Yayasan Peduli Kanker Serviks Indonesia (YPKSI). (2011). www.yayasan peduli kanker servik indonesia 